\title{
Urokinase Plasminogen Activator Receptor in Adipose Tissue Macrophages of Morbidly Obese Subjects
}

\author{
Raffaella Cancello ${ }^{a, b}$ Christine Rouault ${ }^{a} \quad$ Gaël Guilhem ${ }^{a, c}$ Jean-François Bedel ${ }^{a}$ \\ Christine Poitou ${ }^{a}$ Anna Maria Di Blasio ${ }^{\mathrm{b}} \quad$ Arnaud Basdevant $^{\mathrm{a}} \quad$ Joan Tordjman $^{\mathrm{a}}$ \\ Karine Clément ${ }^{\mathrm{a}}$ \\ a Inserm U872, CRC Université Pierre et Marie Curie-Paris 6, CHRU Pitié-Salpétrière, Service de Nutrition, Paris, France \\ ${ }^{b}$ Molecular Biology Laboratory, Centro di Ricerche e Tecnologie Biomediche, Istituto Auxologico Italiano, IRCCS, Milan, Italy \\ ${ }^{c}$ National Institute for Sports (INSEP), Research Department, Laboratory of Biomechanics and Physiology, Paris, France
}

\section{Keywords}

Urokinase plasminogen activator receptor . PLAUR . CD87 - White adipose tissue - Adipocytes · Obesity . Inflammation - Macrophages

\section{Summary}

Objective: At present, circulating markers characterizing the inflammatory infiltration of white adipose tissue (WAT) in human obesity are not well known. We previously identified, by a pangenomic approach (microarrays), the urokinase plasminogen activator receptor (PLAUR or CD87) as a potential marker of subcutaneous adipose tissue macrophage infiltration (ATM). Method: We studied i) the presence of PLAUR protein in WAT; ii) the PLAUR amount in plasma of obese patients; iii) the circulating variations during surgery-induced weight loss, and iv) the correlations between PLAUR circulating levels and bioclinical parameters. Results: We observed that PLAUR is preferentially expressed by infiltrating ATMs, with a typical localization on macrophage membrane. Circulating soluble PLAUR levels were significantly elevated in obese patients compared to lean controls. However, despite a trend towards a decrease 3 months after weight loss, PLAUR plasma levels were not modulated during a 1-year weight loss follow-up, suggesting the contribution of secretion sites other than subcutaneous WAT in obese patients. Conclusions: These findings indicate that PLAUR mRNA expression could be used for the estimation of local subcutaneous ATMs infiltration in obese patients, but it cannot be used as a systemic marker of this inflammatory infiltration in dynamic phases of weight loss.

\section{Introduction}

Human obesity is associated with a 'low-grade' pro-inflammatory profile [1] which can be improved by weight loss $[2,3]$. White adipose tissue (WAT) could be defined by a typical histopathology and contributes to the low-grade inflammation associated with the obese state. In fact, obese WAT is characterized by a variable degree of hypertrophy and hyperplasia of adipocytes, by the accumulation in adipose parenchyma of inflammatory cells as macrophages, and by increased fibrosis depots [4]. The existence of a link between WAT macrophages, BMI, body fat mass, and adipocyte hypertrophy was suggested [3]. Very recently a prominent role for other inflammatory cells as different types of T lymphocytes and mast cells in obese adipose tissue was suggested [5, 6]. Nevertheless, macrophages remain the most abundant inflammatory cells in obese WAT.

The accumulation of adipose tissue macrophages (ATM) is usually quantified by morphometry (light microscopy of a WAT biopsy) [3] or by flow cytometry [7]. No systemic circulating markers of macrophage accumulation are known at present, and a WAT biopsy is still necessary for the estimation of the macrophage amount. Using a previous hypothesis-generating approach - i.e. pangenomic microarrays - in different data sets (i.e. comparison between WAT of obese subjects before and after weight loss, and between isolated adipocytes and stroma vascular fraction (SVF) cells) [3] we identified the urokinase plasminogen activator receptor gene (PLAUR) as being overexpressed in SVF cells as well as modulated by weight loss. In addition, we observed an overexpression of the PLAUR gene in a previously published study focused on the prediction of SVF cells

\section{KARGER}

Fax +497614520714

Information@Karger.de

www.karger.com (c) 2011 S. Karger GmbH, Freiburg

$1662-4025 / 11 / 0041-0017 \$ 38.00 / 0$

Accessible online at:

www.karger.com/ofa
Dr. Raffaella Cancello, $\mathrm{PhD}$

Molecular Biology Laboratory, Centro di Ricerche e Tecnologie Biomediche Istituto Auxologico Italiano, IRCCS

Via G. Zucchi 18, 20095 Cusano Milanino, Milan, Italy

Tel. +3902 61911 30-34, Fax -33

r.cancello@auxologico.it 
derived secretome [8], showing that PLAUR is upregulated only in early stages of adipogenesis in vitro and principally by SVF cells.

The aim of the present study is to assess the relevance of PLAUR as a potential circulating marker of macrophage accumulation in obese WAT. The PLAUR (also known as CD87) is a $55-\mathrm{kD}$ glycoprotein anchored to the plasma membrane that promotes cellular migration through several mechanisms, one of which involves its ability to amplify and focus the expression of urokinase plasminogen activator (uPA) activity to discrete sites of the cell surface $[9,10]$. In addition, PLAUR mediates cellular adhesion to vitronectin [11], promotes integrin-dependent migration [12], and initiates intracellular signalling events $[9,13]$. Even a modest increase in PLAUR expression appears to be biologically significant, because small changes in surface PLAUR binding correlate with the ability of monocytes to penetrate stromal tissue, a well known uPA-dependent process. Thus PLAUR may be a multifunctional receptor, not only involved in promoting pericellular proteolysis but also involved in integrinmediated cell adhesion [12] and migration via interaction with vitronectin $[11,14]$. It has been implicated in intracellular signalling, cellular differentiation, growth, and chemotaxis via a mechanism independent of the enzymatic activity of UPA but dependent on receptor occupancy [15]. Although expression and manipulation of PLAUR gene function have been directly correlated with cellular migration in vitro and with primary tumour growth, tumour-associated neovascularization and metastasis in vivo [16-18] as well as rheumatic [19] and haematological disorders [20], it still remains to be determined whether receptor binding of uPA could be required during other (patho-) biological processes in vivo. Pedersen et al. [21] identified a soluble form of PLAUR (sPLAUR) in ascitic fluid, and circulating PLAUR was also detected in the serum of patients with ovarian cancer [22]. The urokinase plasminogen activator dependent proteolytic cascade, as well as the ligand activation of PLAUR is critically involved in physiological as well as pathophysiological aspects of tissue expansion and remodelling $[10,23]$.

Since the presence of the soluble form of PLAUR in obese patient plasma could correlate with macrophage accumulation in their subcutaneous adipose tissue, PLAUR plasma quantification could be useful to estimate the inflammatory infiltration in subcutaneous WAT, avoiding a surgical biopsy. To investigate this hypothesis, we tested: i) the upregulation of the PLAUR gene in subcutaneous WAT of morbidly obese patients by RTqPCR; ii) the presence of PLAUR protein in ATM by immunohistochemistry (IHC); iii) the circulating PLAUR protein content in obese patient compared to lean control plasma; iv) the correlations between PLAUR plasma levels, ATM percentage in subcutaneous WAT, and bio-clinical parameters; and v) the plasma PLAUR variations during 1 year of surgery-induced weight loss.
Table 1. Clinical and biological parameters of 16 morbidly obese studied subjects $($ mean $\pm \mathrm{SE})$

\begin{tabular}{|c|c|}
\hline Number of patients & 16 \\
\hline Sex (female/male $)$ & $16 / 0$ \\
\hline Age, years & $38.5 \pm 2.8$ \\
\hline$B M I, \mathrm{~kg} / \mathrm{m}^{2}$ & $47.2 \pm 1.8$ \\
\hline \multicolumn{2}{|l|}{ Glucose homeostasis } \\
\hline Glucose, mmol/1 & $5.54 \pm 0.38$ \\
\hline Insulin, $\mu \mathrm{U} / \mathrm{ml}$ & $11.7 \pm 2.3$ \\
\hline QUICKI & 0.34 \\
\hline \multicolumn{2}{|l|}{ Lipid homeostasis } \\
\hline Cholesterol, mmol/1 & $5.2 \pm 0.2$ \\
\hline HDL-cholesterol, mmol/1 & $1.34 \pm 0.1$ \\
\hline Triglycerides, mmol/l & $1.32 \pm 0.1$ \\
\hline \multicolumn{2}{|l|}{ Adipokines } \\
\hline Leptin, ng/ml & $64.5 \pm 6.6$ \\
\hline Adiponectin, $\mu \mathrm{g} / \mathrm{ml}$ & $7.6 \pm 0.5$ \\
\hline \multicolumn{2}{|l|}{ Inflammatory factors } \\
\hline TNF- $\alpha, p g / m l$ & $1.7 \pm 0.1$ \\
\hline IL-6, pg/ml & $2.8 \pm 0.4$ \\
\hline hsCRP, mg/dl & $1.4 \pm 0.2$ \\
\hline Orosomucoid, g/l & $1.01 \pm 0.03$ \\
\hline \multicolumn{2}{|c|}{ Subcutaneous WAT morphometry } \\
\hline Adipocyte mean size, $\mu \mathrm{m}$ & $93.1 \pm 3.2$ \\
\hline Macrophage infiltration, $\%$ & $18.8 \pm 3.7$ \\
\hline
\end{tabular}

\section{Material and Methods}

\section{Patients and Study Design}

Sixteen morbidly obese women involved in a gastric surgery program were recruited at the Department of Nutrition of Pitié-Salpêtrière Hospital (Paris, France). Clinical and biological parameters are shown in table 1. All enrolled patients underwent laparoscopic Roux-en-Y gastric bypass surgery. Preoperative investigations included medical history, and physical, nutritional, cardiopulmonary and psychological evaluations. Obese subjects had been weight stable at least for 3 months before surgery. All patients met the criteria for obesity surgery, i.e. BMI $\geq 40 \mathrm{~kg} / \mathrm{m}^{2}$ or $\geq 35 \mathrm{~kg} / \mathrm{m}^{2}$ with at least one significant co-morbidity (hypertension, type 2 diabetes or dyslipidaemia). The evidence of acute or chronic inflammatory disease, infectious diseases, and cancer were stated as exclusion criteria. Lean controls ( 7 healthy normal weight female; BMI: $21.95 \pm 0.83 \mathrm{~kg} / \mathrm{m}^{2}$; age: $34 \pm 2.25$ years; adipocyte size $62.4 \pm 2.28 \mu \mathrm{m}$; mean \pm standard error $(\mathrm{SE}))$ were patients undergoing surgery for aesthetic reasons. The Ethics Committees of the PitiéSalpêtrière Hospital, Paris, France approved the clinical investigations, and all subjects gave signed informed consent after an individual explanation.

\section{Immuno-Morphological Analysis of Adipose Tissue}

Periumbilical subcutaneous abdominal WAT surgical biopsies were the same as collected and used for a previous study [3]. A portion of each WAT biopsy was immediately transferred into liquid nitrogen until total RNA extraction. Another fragment of the same sample was fixed overnight at $4{ }^{\circ} \mathrm{C}$ in $4 \%$ paraformaldehyde and then processed for standard paraffin embedding procedure. Sections of $5 \mu \mathrm{m}$ were stained as described below and observed under a Zeiss 20 Axiostar Plus microscope (Zeiss, Jena, Germany). Pictures of histological sections were captured by a digital camera (TriCCD, Sony, Paris, France). Immunohistochemical detection of HAM56 (1:200; Dako Cytomation, Trappes, France) and CD68 (1:100, Santa Cruz Biotechnologies, Heidelberg, Germany) were 
Fig. 1. a PLAUR mRNA (grey blocks) and PAI-1 mRNA (dark blocks) expression (normalized on $18 \mathrm{~S}$ expression and expressed as $\mathrm{AU}$ in obese $(\mathrm{OB}, \mathrm{n}=16)$ versus lean controls $(\mathrm{C}, \mathrm{n}=7) . *$ p value $<0.01 \mathrm{OB}$ versus $\mathrm{C}$.

b Correlations between macrophage content (\%) and

PLAUR gene expression (by RTqPCR,

AU) in obese sWAT at basal condition (T0, $\mathrm{n}=16$ ) (left panel) and between the variation of sWAT macrophage content (delta sWAT macrophage content $3 \mathrm{M} / \mathrm{T} 0, \%)$ and the variation of PLAUR expression levels by microarrays (delta ratio before/after surgery $(3 \mathrm{M} / \mathrm{T} 0, \mathrm{AU}$, $\mathrm{n}=10$ ) (right panel). c PLAUR, tPA, and uPA gene expression (by RTqPCR), normalized on $18 \mathrm{~S}$ expression, in obese patients regrouped by the median of macrophage content (\%) in sWAT. Patients with a high degree of infiltration (OB-High, black blocks, $\mathrm{n}=8$ ) and patients with lower macrophage infiltration levels (OB-Low, grey blocks, $\mathrm{n}=8$ ) are shown; $\mathrm{AU}=$ arbitrary units; *p value $<0.05$ OBHigh versus OB-Low.
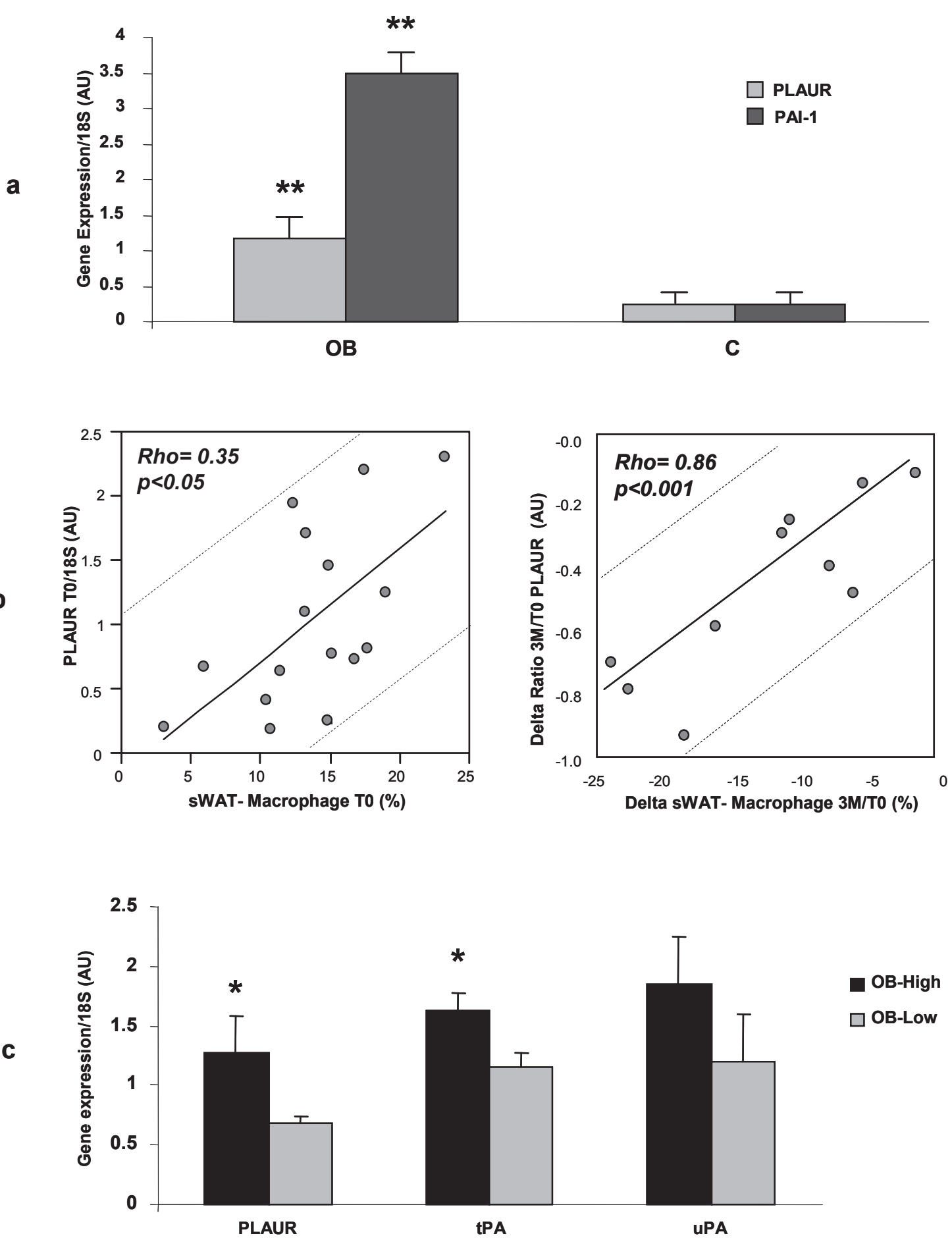

performed for macrophage counting as previously described [3]. Immunohistochemical detection of PLAUR (R and D Systems, Lille, France) was performed with the avidin-biotin peroxidase method [24]. Briefly, dewaxed sections were processed through the following incubation steps: i) antigen unmasking by $750 \mathrm{~W}$ microwave washing in a solution of citrate buffer $10 \mathrm{mmol} / \mathrm{l}, \mathrm{pH} 6.0$, three times for $5 \mathrm{~min}$ each; ii) hydrogen peroxide 3\% in water for 15 min to block endogenous peroxidases; iii) TrisBuffered Saline/Tween 20/Casein 0.02M solution (TBS-TC) washing for 5 min; iv) incubation with polyclonal goat anti-human PLAUR antibody diluted 1:50 in TBS-TC overnight at $4{ }^{\circ} \mathrm{C}$; v) incubation with multilink anti-goat biotinylated immunoglobulins (Dako Cytomation) diluted 1:200 in TBS-TC for $20 \mathrm{~min}$ at room temperature. Standard streptavidin-biotinperoxidase complex method was applied using a commercially available kit (ABCYS Biospa, Milan, Italy), and the staining was visualized using diaminobenzidine (Dako Cytomation). Slides were counterstained with Mayer's haematoxylin. Method specificity tests were performed by omission of primary antibodies and/or use of pre-immune serum.

Total RNA Extraction, Real Time Quantitative PCR (RTqPCR), and Microarrays

Total RNA from subcutaneous WAT (sWAT), both from obese $(\mathrm{n}=16)$ and lean $(\mathrm{n}=7)$ subjects, was prepared using the RNeasy Mini Kit (Qia- 
gen, Courtaboeuf, France) following manufacturer instructions. Total RNA was also extracted from SVF cells, preadipocytes, adipocytes, and ATMs isolated from sWAT of 5 additional obese patients (female, age $46.2 \pm 5.5$ years; BMI $45 \pm 6.7 \mathrm{Kg} / \mathrm{m}^{2}$; mean $\pm \mathrm{SD}$ ), as previously described [3]. Reverse transcription and real-time quantitative polymerase chain reaction (RTqPCR) were performed as described in [25]. We used $18 \mathrm{~S}$ ribosomal RNA (rRNA Control TaqMan Assay kit; Applied Biosystems, Foster City, CA, USA) to normalize gene expression; primers for PLAUR, plasminogen activator inhibitor-1 (PAI-1), tissue plasminogen activator (tPA) and urokinase plasminogen activator (uPA) mRNA were obtained from Applied Biosystems. These probes were labelled with a reporter dye (FAM) on the 5'-end. The relative gene expression quantification was calculated by the delta-CT method. We used sWAT total RNA of a subset of 10 obese subjects (of the collected 16) to perform microarray tests before (T0) versus 3 months $(3 \mathrm{M})$ after bariatric surgery intervention, as previously described [3]

\section{Laboratory Tests}

Blood samples were collected after an overnight fasting of $12 \mathrm{~h}$. Glycaemia was measured enzymatically. Serum insulin concentrations were measured using a commercial IRMA kit (Bi-INSULINE IRMA, CisBio International, Bagnols-sur-Cèze, France). Serum leptin and adiponectin were determined using a radioimmunoassay kit from Linco Research (Saint Louis, MI, USA) according to the manufacturer's recommendations. The sensitivity of these assays was $0.5 \mathrm{ng} / \mathrm{ml}$ and $0.8 \mathrm{ng} / \mathrm{ml}$ for leptin and adiponectin, respectively. Serums levels of interleukin 6 (IL-6) were measured by an ultrasensitive ELISA system (Quantikine US, R and D System Europe Ltd., Abington, UK). The sensitivity of this assay was $<0.104 \mathrm{pg} / \mathrm{ml}$. PLAUR plasmatic levels were systematically measured from obese patient serum before (T0) and $3(3 \mathrm{M}), 6(6 \mathrm{M})$, and $12(12 \mathrm{M})$ months after surgery (lap-banding or bypass). An ELISA test (HuPLAUR, Quantikine High Sensivity, R and D System Europe Ltd.) was used following manufacturer instructions. Plasma samples from 7 women affected by ovary cancer (BMI $\leq 25 \mathrm{~kg} / \mathrm{m}^{2}$ ) and from 7 lean healthy non-obese women $\left(\mathrm{BMI} \leq 26 \mathrm{~kg} / \mathrm{m}^{2}\right)$ were used as positive and negative controls, respectively.

\section{Statistical Analysis}

Data are expressed as mean \pm SE. The Shapiro-Wilcoxon test was used to test the Gaussian distribution of all clinical and biological parameters. Skewed variables were log-transformed to normalize their distribution before statistical analyses. The normality of log-transformed variables was systematically tested. Relationships between PLAUR plasma levels and quantitative clinical and biological variables were explored by logistic regression (Spearman's Rho or Pearson R). Analysis of variance (ANOVA) was used for quantitative traits. Statistical analysis was performed with JMP statistics software (SAS Institute Inc., Cary, NC, USA). A p value $<0.05$ was considered significant

\section{Results}

\section{PLAUR Gene Expression in Subcutaneous WAT is Associated} with Adipose Tissue Macrophage Amount

We first examined the gene expression level of PLAUR in sWAT of obese vs. lean controls. As shown in figure 1a, PLAUR was significantly more expressed in sWAT of obese subjects $(p=0.0041)$ compared to lean controls $(C)$. As expected, also the gene expression of the PAI-1 (a PLAURspecific adipocyte-derived antagonist) was up-regulated in the sWAT of our obese subjects (fig. 1a). We then checked whether PLAUR gene expression was correlated with the
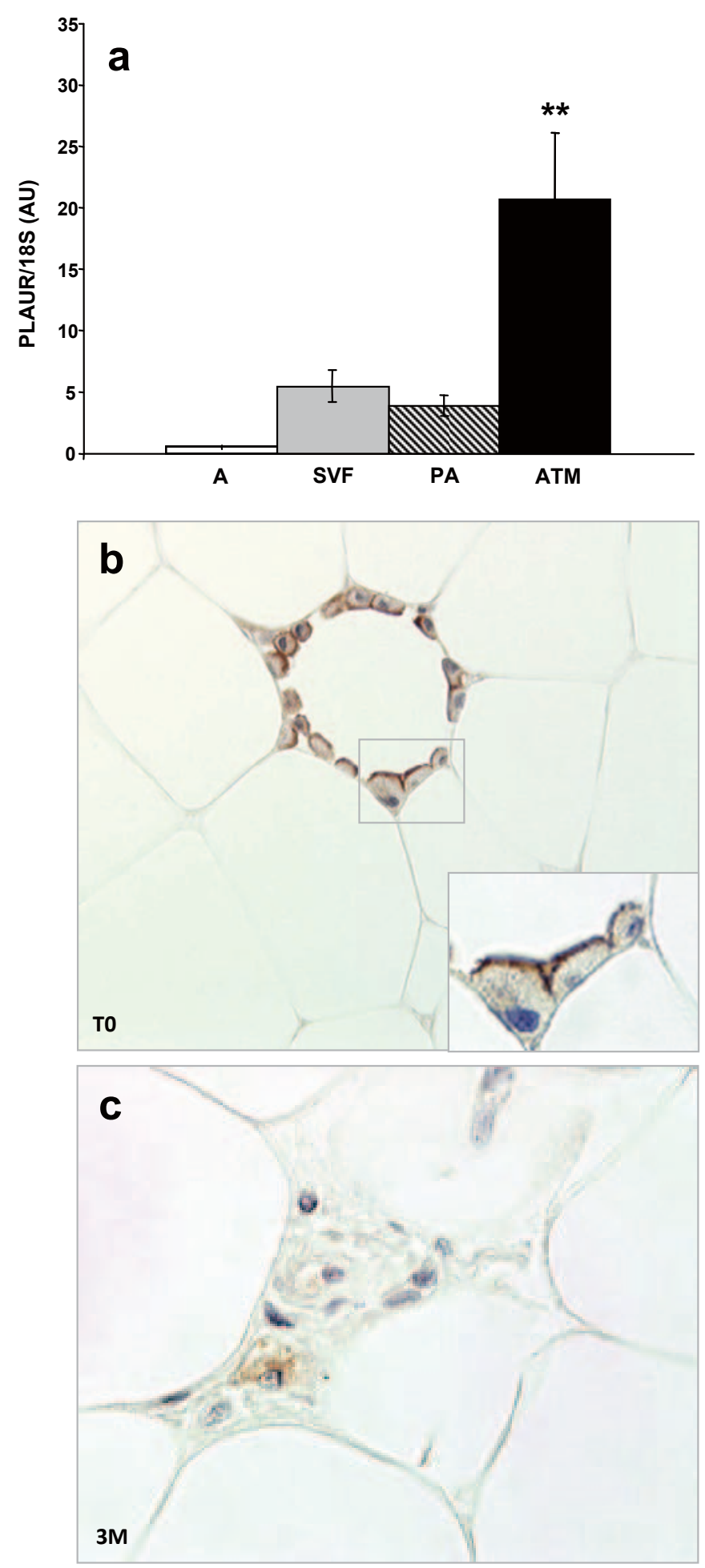

Fig. 2. a PLAUR gene expression (by RTqPCR) in mature adipocytes (A), in the adipose tissue stroma vascular fraction cells (SVF), in isolated preadipocytes (PA) and in isolated adipose tissue macrophages (ATM) of obese subjects $(n=5)$. PLAUR expression values were normalized on $18 \mathrm{~S}$ expression levels and indicated as arbitrary units (AU); ** p value $<0.01$ ATM versus A, SVF and PA. b Detection of PLAUR protein in subcutaneous WAT by immunohistochemistry. PLAUR immunopositivity concentrated on adipose tissue macrophage surface $(\times 40)$ in obese subjects at baseline (T0) (enlarged in the inset, $\times 60$ ). c Three months after surgery-induced weight loss $(3 \mathrm{M})$, the resting isolated macrophages showed a cytoplasm staining $(\times 60)$. 

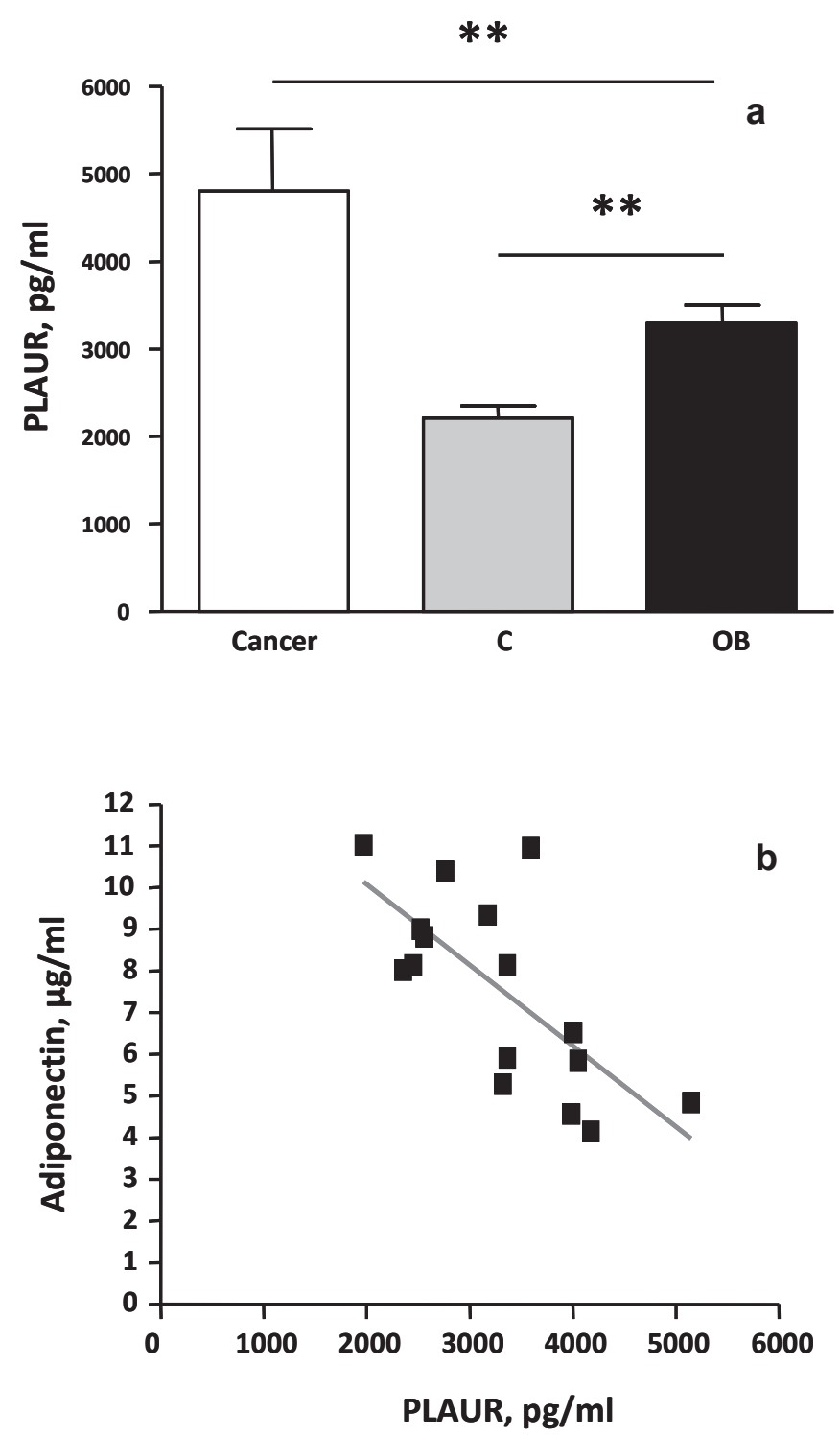

Fig. 3. a Detection of soluble PLAUR protein $(\mathrm{pg} / \mathrm{ml})$ in serum of ovarian cancer patients (Cancer, $n=7)$, of lean controls $(C, n=7)$ and of obese patients $(\mathrm{OB}, \mathrm{n}=16)$ by ELISA assay; ${ }^{*} \mathrm{p}$ value $<0.01$. b Negative significant correlation $(\mathrm{Rho}=-0.66, \mathrm{p}<0.01)$ between adiponectin circulating levels $(\mu \mathrm{g} / \mathrm{ml})$ and soluble PLAUR circulating levels $(\mathrm{pg} / \mathrm{ml})$ in obese patients $(\mathrm{n}=16)$ at basal state.

change in sWAT macrophages before and after weight loss. We observed that PLAUR gene expression in sWAT (before surgery, T0) positively correlated with macrophage accumulation percentage (before surgery, T0) in weight stable morbidly obese subjects $(\mathrm{R}=0.35, \mathrm{p}<0.05)$ (fig. $1 \mathrm{~b}$, left panel). Moreover, by the microarrays analysis of sWAT, in a subset of 10 patients from the 16 collected, we observed a $60 \%$ decrease in PLAUR gene expression in sWAT 3 months after bariatric surgery, with a parallel decrease in macrophage content (\%). This change in gene expression correlated significantly with the change in percentage of sWAT macrophages 3 months after surgery (delta $3 \mathrm{M} / \mathrm{T} 0$ ) (Spearman's Rho $=0.86, \mathrm{p}=$ 0.0009 ) (fig. 1b, right panel). We then divided the patients in two subgroups based on the median value of macrophage accumulation percentage in sWAT: one group $(n=8)$ had a macrophage accumulation percentage above the median of the ATM percentage distribution (indicated as OB-High, $17 \pm 1.2 \%$, mean ATM $\% \pm \mathrm{SE})$ and the other group $(\mathrm{n}=8)$ had macrophage accumulation percentage below the median of the distribution (OB-Low, $9.4 \pm 1.4 \%$, mean ATM $\% \pm \mathrm{SE}$ ). We then observed that PLAUR and tissue type tPA genes were significantly upregulated in sWAT of the OB-High group ( $p=0.03$, fig. $1 \mathrm{c}$ ). The expression of the urokinase plasminogen activator (uPA) gene was not significantly different in the two groups, despite an upregulating trend in OB-High group (fig. 1c).

\section{PLAUR is Preferentially Expressed by Infiltrating ATMs}

We have previously shown that PLAUR gene is overexpressed in the SVF cells of human sWAT and it is modulated during weight loss [3]. Since SVF cells are a heterogeneous pool of different cell types, we decided to study the PLAUR gene expression in SVF cells compared to isolated preadipocytes, to isolated mature adipocytes and to ATM by RTqPCR. We observed that the PLAUR gene is significantly overexpressed only in ATM ( $p=0.0047)$ (fig. 2a). We then performed an immunohistochemical study to detect the cell types expressing the PLAUR protein in obese subcutaneous WAT. Before the surgery (our basal condition, T0), the immunopositivity signal was detected only in ATMs of subcutaneous WAT. All mature adipocytes tested negative. Interestingly, the immuno-positivity pattern of staining was concentrated on the macrophage cell membranes, rather that the cytoplasm area. This feature was clearly visible in the membranes of macrophages surrounding mature adipocytes (fig. 2b). After 3 months weight loss (3M), we previously showed that the macrophage content decreased in this subject group [3]. We now show that the remaining ATMs tested positive for PLAUR immuno-staining, but the positivity was mainly cytoplasmic, rather than on the cell surface membranes, as at T0 (fig. 2c).

Plasma Levels of Soluble PLAUR are Upregulated in Human Obesity and Correlate with Metabolic Parameters but not with Macrophage Accumulation in WAT

The circulating levels of soluble PLAUR in obese and nonobese subjects were tested and then the relationships between PLAUR circulating levels, various metabolic and inflammatory parameters, and macrophage accumulation in obese subjects were assessed. The total amount of soluble PLAUR protein was significantly higher in obese subjects $(\mathrm{p}<0.05)$ compared to lean controls (mean \pm SE: 3,295.9 \pm 210.83 vs. 2,675.9 $\pm 59.28 \mathrm{pg} / \mathrm{ml}, \mathrm{p}<0.05$ ) (fig. $3 \mathrm{a}$ ). However, the circulating levels of PLAUR were significantly lower in obese subjects compared to the levels observed in ovarian cancer patients (used as positive controls) (fig. 3a). At baseline, soluble PLAUR circulating levels were positively correlated with the circulat- 
Table 2. Clinical and biological parameters (mean \pm SE) of 16 morbidly obese female subjects in basal state (basal (T0)) and 3, 6 and 12 months after surgical induced weight loss

\begin{tabular}{|c|c|c|c|c|}
\hline & \multirow[t]{2}{*}{ Basal (T0) } & \multicolumn{3}{|c|}{ Weight loss follow-up } \\
\hline & & 3 months & 6 months & 12 months \\
\hline Adipocyte mean size, $\mu m$ & $93.1 \pm 3.2$ & $82.3 \pm 5.5^{\mathrm{a}}$ & - & - \\
\hline$A T M, \%$ & $18.8 \pm 3.7$ & $14.1 \pm 3.3^{\mathrm{a}}$ & - & - \\
\hline \multicolumn{5}{|l|}{ Glucose homeostasis } \\
\hline $\mathrm{BMI}, \mathrm{kg} / \mathrm{m}^{2}$ & $47.2 \pm 1.8$ & $39.9 \pm 1.3^{\mathrm{a}}$ & $37.7 \pm 1.5^{\mathrm{a}}$ & $33.6 \pm 1.3^{\mathrm{a}}$ \\
\hline Glucose, $\mathrm{mmol} / \mathrm{l}$ & $5.54 \pm 0.4$ & $5.2 \pm 0.02^{\mathrm{a}}$ & $5.1 \pm 0.03^{\mathrm{a}}$ & $4.8 \pm 0.02^{\mathrm{a}}$ \\
\hline Insulin, $\mu \mathrm{U} / \mathrm{ml}$ & $11.7 \pm 2.3$ & $6.6 \pm 0.76^{\mathrm{a}}$ & $5.8 \pm 0.57^{\mathrm{a}}$ & $4.5 \pm 0.59^{\mathrm{a}}$ \\
\hline \multicolumn{5}{|l|}{ Lipid homeostasis } \\
\hline Cholesterol, mmol/1 & $5.2 \pm 0.2$ & $4.9 \pm 0.2$ & $5.2 \pm 0.2$ & $5.01 \pm 0.2$ \\
\hline HDL-cholesterol, mmol/l & $1.3 \pm 0.1$ & $1.3 \pm 0.1$ & $1.4 \pm 0.1$ & $1.7 \pm 0.1^{\mathrm{a}}$ \\
\hline Triglycerides, mmol/l & $1.3 \pm 0.1$ & $1.1 \pm 0.1$ & $1.2 \pm 0.1$ & $0.9 \pm 0.1^{\mathrm{a}}$ \\
\hline \multicolumn{5}{|l|}{ Adipokines } \\
\hline Leptin, ng/ml & $64.5 \pm 6.6$ & $36.1 \pm 3.9^{\mathrm{a}}$ & $29.9 \pm 3.8^{\mathrm{a}}$ & $26.3 \pm 3.4^{\mathrm{a}}$ \\
\hline Adiponectin, $\mu \mathrm{g} / \mathrm{ml}$ & $7.6 \pm 0.5$ & $8.9 \pm 0.8^{\mathrm{a}}$ & $9.4 \pm 0.7^{\mathrm{a}}$ & $12.3 \pm 0.8^{\mathrm{a}}$ \\
\hline \multicolumn{5}{|l|}{ Inflammatory factors } \\
\hline TNF- $\alpha, p g / m l$ & $1.7 \pm 0.1$ & $1.8 \pm 0.1$ & $1.6 \pm 0.1$ & $1.4 \pm 0.1^{\mathrm{a}}$ \\
\hline IL-6, pg/ml & $2.8 \pm 0.4$ & $2.3 \pm 0.3^{\mathrm{a}}$ & $1.7 \pm 0.1^{\mathrm{a}}$ & $0.97 \pm 0.1^{\mathrm{a}}$ \\
\hline hsCRP, mg/dl & $1.4 \pm 0.2$ & $0.7 \pm 0.1^{\mathrm{a}}$ & $0.4 \pm 0.1^{\mathrm{a}}$ & $0.2 \pm 0.1^{\mathrm{a}}$ \\
\hline Orosomucoid, g/l & $1.01 \pm 0.03$ & $0.9 \pm 0.04$ & $0.8 \pm 0.03^{\mathrm{a}}$ & $0.7 \pm 0.03^{\mathrm{a}}$ \\
\hline
\end{tabular}

${ }^{\mathrm{a}} \mathrm{p}$ value $<0.05$ versus basal $(\mathrm{T} 0)$. ing levels of fasting insulin $(\mathrm{Rho}=0.59, \mathrm{p}=0.01)$ and HOMA index $(\mathrm{Rho}=0.48, \mathrm{p}=0.05)$ and negatively with the QUICKI index (Spearman's Rho $=-0.48, \mathrm{p}=0.04$ ). A negative correlation was also found between serum adiponectin levels and soluble PLAUR basal levels (Spearman's Rho $=-0.66, \mathrm{p}=$ 0.005 ) (fig. 3b). Inflammatory circulating parameters (such as IL-6, TNF- $\alpha$, orosomucoid, SAA, hsCRP) and other metabolic parameters (such as leptin, triglycerides, total cholesterol) did not correlate with plasma PLAUR levels. In addition, no correlation was found between circulating PLAUR levels and the percentage of macrophage accumulation measured in the adipose tissue parenchyma, nor with adipocyte hypertrophy in the basal condition (T0).

\section{Effect of Weight Loss on PLAUR Plasma Levels}

The table 2 shows changes in clinical, metabolic, and biological parameters, as well as in the inflammatory profile in the 16 obese women before (T0), 3 months (3M), 6 months (6M), and 1 year $(12 \mathrm{M})$ after gastric surgery. The surgery-induced weight loss was associated, as expected, with a significant decrease in BMI and fat mass, and with a significant improvement in glucose, lipid and inflammatory parameters (table 2). The PLAUR circulating levels significantly decreased only $3 \mathrm{M}$ after weight loss (fig. 4), but after $6 \mathrm{M}$ and $12 \mathrm{M}$ no significant changes were observed compared to the baseline levels. However, in the studied cohort, the metabolic and inflammatory parameters continued to improve, as well as inflammation of adipose tissue and adipocyte hypertrophy (table 2). We did not find a correlation between circulating PLAUR

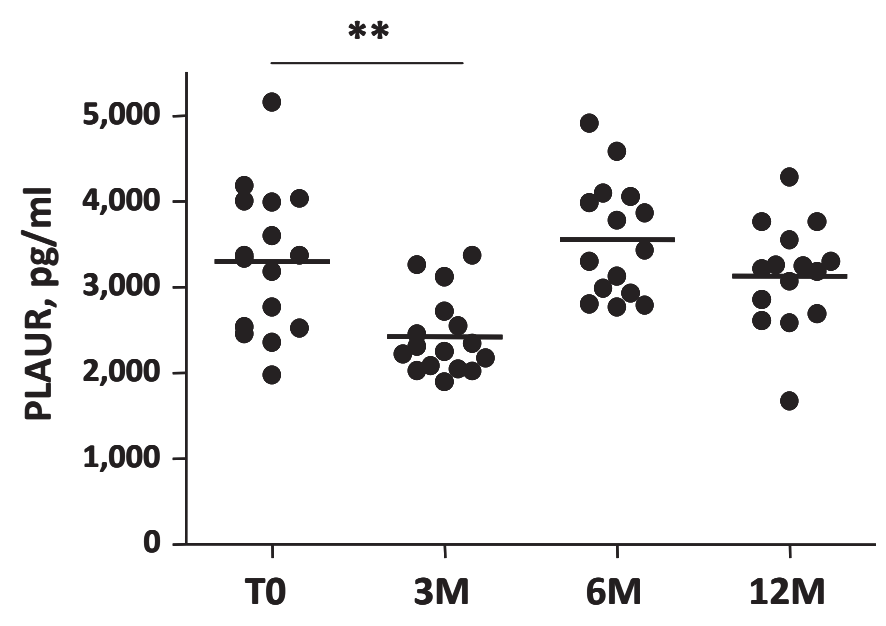

Fig. 4. Detection of circulating PLAUR protein levels $(\mathrm{pg} / \mathrm{ml})$ in basal condition (T0) and 3 months (3M), 6 months (6M), 1 year (12M) after surgically induced weight loss $(\mathrm{n}=16) ; * *$ p value $<0.01$.

levels and the percentage of macrophage accumulation measured in the adipose tissue parenchyma after weight loss (3M), nor with $3 \mathrm{M}$ adipocyte hypertrophy.

\section{Discussion}

The discovery of macrophage accumulation in human WAT has challenged the identification of local and circulating markers reflecting this type of inflammatory cell accumulation. We 
showed here that increased gene expression of PLAUR, assessed by RTqPCR, in morbidly obese subjects correlates with the amount of macrophage accumulation in subcutaneous WAT. In addition, separating the different cellular fractions that compose the SVF, we demonstrated that PLAUR is selectively overexpressed in macrophages that infiltrate adipose tissue. In the immunohistochemistry experiments, adipocytes tested negative, suggesting that PLAUR could be a useful marker for macrophage detection in human WAT. The expression of PLAUR on the macrophage membrane surface may indicate an activated phenotype [26], and it was never shown before in infiltrating adipose tissue macrophages. Further studies are needed to asses whether the observed PLAUR immuno-staining is a peculiar characteristic of macrophages resident in adipose tissue or a generic feature of a pro-inflammatory state. While PLAUR stains positive mostly on the macrophage membrane before surgery, our data show an unsuspected involvement of PLAUR since their membrane expression was not detectable in isolated resting macrophage in subcutaneous WAT 3 months after weight loss. We observed rather a cytoplasm positivity in WAT dispersed macrophages after weight loss $(3 \mathrm{M})$. Since calorie restriction and fat mass loss are able to modulate the inflammatory profile of adipose tissue, it is possible that this phenomenon is able to affect the fine regulation of PLAUR migration to the cell membrane. Further studies are required to test this hypothesis. Although we cannot exclude that PLAUR is expressed in other cells of the stroma vascular fraction, the preferential staining of PLAUR in WAT macrophages is in good agreement with previous studies in which PLAUR was detected in vitro on human monocytes and in vivo on tumourassociated macrophages of different tumour types [27-29]. The receptor bound uPA on macrophage cell surface could play a role in extracellular matrix degradation for macrophage migration and enhancing of tumour invasion [29]. In obesity, adipose tissue contains a dramatically increased number of macrophages, and in some circumstances macrophages can constitute up to $40 \%$ of the cell population within an adipose tissue depot $[30,31]$. Macrophages are obviously a potential source of secreted pro-inflammatory and antiinflammatory factors [31]. At present, the mechanism of macrophage recruitment in adipose tissue has not been defined, but it presumably involves increased secretion of chemotactic molecules by adipose tissue. Amongst others, candidates are C-C motif chemokine ligand 2 (CCL2; also known as monocyte chemoattractant protein-1) [32] and CCL5 [33]. A macrophage secretion of uPA or tPA sustaining this phenomenon cannot be excluded. In vivo studies have indicated that PLAUR is an integral element of the immune response and chemotaxis, since a dramatic reduction of inflammatory cells migration in infected PLAUR ${ }^{-/}$mice was observed [34]. The molecular regulation of the expression and membrane migration of this receptor may modulate their chemoattractant functions, as well as their role in extracellular matrix proteoly- sis [35]. Further cellular studies are certainly needed to clarify these mechanisms.

A significant correlation between circulating PLAUR levels and HOMA index as well as with fasting insulin levels was observed. It is still not clear, at present, whether ATMs content and insulin resistance are causally related in humans. It remains possible that ATMs represent a marker, rather than a cause, of insulin resistance, and perhaps macrophages impair systemic insulin sensitivity through some other mechanisms and/or probably by soluble factors secreted by macrophages that act locally or systemically. Soluble PLAUR is increased in several types of cancer and we show here their significant increase also in obesity, compared to lean control plasma. Recently, an in vitro induction of UPA/PLAUR by insulin-like growth factor-I (IGF-I) in mice has been shown [36]. Nevertheless, data on PLAUR signalling pathways and insulin effects in humans are still lacking. The significant negative correlation found between serum adiponectin and soluble PLAUR could suggest that adiponectin may have a role in macrophage polarization regulation, favouring an anti-inflammatory phenotype in infiltrating macrophages as well in circulating monocytes [37].

In our studied cohort, soluble PLAUR levels show an interesting pattern with a first drop 3 months after surgery and a return to its initial levels 6 and 12 months after bariatric surgery intervention. Body fat mass, insulin sensitivity, and other metabolic parameters continue to improve at these same time-points. In these patients, adipose tissue samples were not available at longer follow-up times ( 6 and 12 months), and the profile of macrophage evolution cannot then be defined. Finally, we cannot conclude about the adipose tissue contribution on circulating PLAUR levels. A longer follow-up is certainly necessary to clarify the circulating levels, with concomitant analysis of the PLAUR pattern in adipose tissue and serum.

This study has been performed on a limited sample of 16 obese patients. It would be interesting to refine our results by considering a larger cohort of obese patients. Moreover, our sample consisted only of women, and we cannot exclude a gender effect on adipose tissue PLAUR expression. A similar analysis in a population of obese men could eventually reveal sex differences in PLAUR expression as well as in PLAUR circulating levels. However, the present results suggest the influence of calorie intake changes in PLAUR serum regulation on the one hand and on the other hand that several tissues may contribute to the secretion of this factor in plasma of obese women. A post-transcriptional regulation of PLAUR protein cannot be excluded in infiltrating ATMs, since this regulating pathway was already demonstrated in mice and in human bronchial epithelial cells under lipopolysaccharide stimulation [38]. The specific role of PLAUR in the modulation of adipose tissue inflammation, as well as the clinical significance of PLAUR increased circulating levels in morbidly obese patients, remains to be elucidated. 
In conclusion, it is shown here that ATMs in obese patients express PLAUR and that only mRNA expression levels are in correlation with the percentage of macrophage infiltration in subcutaneous WAT. In obese subject serum, the soluble receptor is increased compared to lean controls, therefore the detected amount did not correlate with ATMs estimation, suggesting other different secretion sites and/or a possible posttranscriptional regulation of this secreted protein. The RNA expression levels of the PLAUR gene could then be useful to estimate sWAT macrophage infiltration, but PLAUR circulating levels cannot be used as a systemic marker of ATMs.

\section{Disclosure Statement}

The authors declare no conflicts of interest.

\section{References}

1 Cancello R, Taleb S, Poitou C, Tordjman J, Lacasa $\mathrm{D}$, Guerre-Millo M, Clement K: Is obesity an inflammatory disease? Journ Annu Diabetol Hotel Dieu 2006:115-128.

2 Capel F, Klimcakova E, Viguerie N, Roussel B, Vitkova M, Kovacikova M, Polak J, Kovacova Z, Galitzky J, Maoret JJ, Hanacek J, Pers TH, Bouloumie A, Stich V, Langin D: Macrophages and adipocytes in human obesity: adipose tissue gene expression and insulin sensitivity during calorie restriction and weight stabilization. Diabetes 2009;58: $1558-1567$.

$\checkmark 3$ Cancello R, Henegar C, Viguerie N, Taleb S, Poitou C, Rouault C, Coupaye M, Pelloux V, Hugo D, Bouillot JL, Bouloumie A, Barbatelli G, Cinti S, Svensson PA, Barsh GS, Zucker JD, Basdevant A, Langin D, Clement K: Reduction of macrophage infiltration and chemoattractant gene expression changes in white adipose tissue of morbidly obese subjects after surgery-induced weight loss. Diabetes 2005;54:2277-2286.

4 Henegar C, Tordjman J, Achard V, Lacasa D, Cremer I, Guerre-Millo M, Poitou C, Basdevant A, Stich V, Viguerie N, Langin D, Bedossa P, Zucker JD, Clement K: Adipose tissue transcriptomic signature highlights the pathological relevance of extracellular matrix in human obesity. Genome Biol 2008;9:R14.

5 Sell H, Eckel J: Adipose tissue inflammation: novel insight into the role of macrophages and lymphocytes. Curr Opin Clin Nutr Metab Care 2010.

6 Clement K, Viguerie N, Poitou C, Carette C, Pelloux V, Curat CA, Sicard A, Rome S, Benis A, Zucker JD, Vidal H, Laville M, Barsh GS, Basdevant A, Stich V, Cancello R, Langin D: Weight loss regulates inflammation-related genes in white adipose tissue of obese subjects. FASEB J 2004;18:1657-1669.

7 Bourlier V, Zakaroff-Girard A, Miranville A, De Barros S, Maumus M, Sengenes C, Galitzky J, Lafontan M, Karpe F, Frayn KN, Bouloumie A: Remodeling phenotype of human subcutaneous adipose tissue macrophages. Circulation 2008;117: 806-815.

8 Mutch DM, Rouault C, Keophiphath M, Lacasa D, Clement K: Using gene expression to predict the secretome of differentiating human preadipocytes. Int J Obes (Lond) 2009;33:354-363.

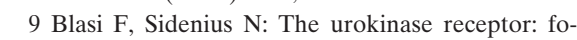
cused cell surface proteolysis, cell adhesion and signaling. FEBS Lett 2010;584:1923-1930.

10 Montuori N, Ragno P: Multiple activities of a multifaceted receptor: roles of cleaved and soluble PLAUR. Front Biosci 2009;14:2494-2503.

11 Wei Y, Waltz DA, Rao N, Drummond RJ, Rosenberg S, Chapman HA: Identification of the urokinase receptor as an adhesion receptor for vitronectin. J Biol Chem 1994;269:32380-32388.
12 Reuning U, Magdolen V, Hapke S, Schmitt M: Molecular and functional interdependence of the urokinase-type plasminogen activator system with integrins. Biol Chem 2003;384:1119-1131.

13 Wei Y, Eble JA, Wang Z, Kreidberg JA, Chapman HA: Urokinase receptors promote beta1 integrin function through interactions with integrin alpha3beta1. Mol Biol Cell 2001;12:2975-2986.

14 Selleri C, Montuori N, Ricci P, Visconte V, Carriero MV, Sidenius N, Serio B, Blasi F, Rotoli B, Rossi G, Ragno P: Involvement of the urokinase-type plasminogen activator receptor in hematopoietic stem cell mobilization. Blood 2005;105:2198-2205.

15 Barinka C, Parry G, Callahan J, Shaw DE, Kuo A, Bdeir K, Cines DB, Mazar A, Lubkowski J: Structural basis of interaction between urokinase-type plasminogen activator and its receptor. J Mol Biol 2006;363:482-495.

16 Abe J, Urano T, Konno H, Erhan Y, Tanaka T, Nishino N, Takada A, Nakamura S: Larger and more invasive colorectal carcinoma contains larger amounts of plasminogen activator inhibitor type 1 and its relative ratio over urokinase receptor correlates well with tumor size. Cancer 1999;86:26022611.

17 Aref S, El-Sherbiny M, Mabed M, Menessy A, ElRefaei M: Urokinase plasminogen activator receptor and soluble matrix metalloproteinase- 9 in acute myeloid leukemia patients: a possible relation to disease invasion. Hematology 2003;8:385-391.

18 Begum FD, Hogdall CK, Kjaer SK, Christensen L, Blaakaer J, Bock JE, Glud E, Hoyer-Hansen G, Ring-Larsen H, Hogdall EV: The prognostic value of plasma soluble urokinase plasminogen activator receptor (sPLAUR) levels in stage III ovarian cancer patients. Anticancer Res 2004;24:1981-1985.

19 Slot O, Brunner N, Locht H, Oxholm P, Stephens RW: Soluble urokinase plasminogen activator receptor in plasma of patients with inflammatory rheumatic disorders: increased concentrations in rheumatoid arthritis. Ann Rheum Dis 1999;58:488492.

20 Bene MC, Castoldi G, Knapp W, Rigolin GM, Escribano L, Lemez P, Ludwig WD, Matutes E, Orfao A, Lanza F, van't Veer M, EGIL, European Group on Immunological Classification of Leukemias: CD87 (urokinase-type plasminogen activator receptor), function and pathology in hematological disorders: a review. Leukemia 2004;18:394-400.

21 Pedersen N, Schmitt M, Ronne E, Nicoletti MI, Hoyer-Hansen G, Conese M, Giavazzi R, Dano K, Kuhn W, Janicke F: A ligand-free, soluble urokinase receptor is present in the ascitic fluid from patients with ovarian cancer. J Clin Invest 1993;92: 2160-2167.
22 Sier CF, Stephens R, Bizik J, Mariani A, Bassan M, Pedersen N, Frigerio L, Ferrari A, Dano K, Brunner $\mathrm{N}$, Blasi F: The level of urokinase-type plasminogen activator receptor is increased in serum of ovarian cancer patients. Cancer Res 1998;58:1843-1849.

23 Montuori N, Carriero MV, Salzano S, Rossi G, Ragno P: The cleavage of the urokinase receptor regulates its multiple functions. J Biol Chem 2002; 277:46932-46939.

24 Hsu SM, Raine L: Protein A, avidin, and biotin in immunohistochemistry. J Histochem Cytochem 1981;29:1349-1353.

25 Viguerie N, Clement K, Barbe P, Courtine M, Benis A, Larrouy D, Hanczar B, Pelloux V, Poitou C, Khalfallah Y, Barsh GS, Thalamas C, Zucker JD, Langin D: In vivo epinephrine-mediated regulation of gene expression in human skeletal muscle. J Clin Endocrinol Metab 2004;89:2000-2014.

26 Min HY, Semnani R, Mizukami IF, Watt K, Todd RF 3rd, Liu DY: cDNA for Mo3, a monocyte activation antigen, encodes the human receptor for urokinase plasminogen activator. J Immunol 1992; 148:3636-3642.

27 Pyke C, Kristensen P, Ralfkiaer E, GrondahlHansen J, Eriksen J, Blasi F, Dano K: Urokinasetype plasminogen activator is expressed in stromal cells and its receptor in cancer cells at invasive foci in human colon adenocarcinomas. Am J Pathol 1991;138:1059-1067.

28 Pyke C, Graem N, Ralfkiaer E, Ronne E, HoyerHansen G, Brunner N, Dano K: Receptor for urokinase is present in tumor-associated macrophages in ductal breast carcinoma. Cancer Res 1993;53: 1911-1915.

29 Blasi F: Urokinase and urokinase receptor: a paracrine/autocrine system regulating cell migration and invasiveness. Bioessays 1993;15:105-111.

30 Bouloumie A, Casteilla L, Lafontan M: Adipose tissue lymphocytes and macrophages in obesity and insulin resistance: makers or markers, and which comes first? Arterioscler Thromb Vasc Biol 2008; 28:1211-1213.

31 Bouloumie A, Curat CA, Sengenes C, Lolmede K, Miranville A, Busse R: Role of macrophage tissue infiltration in metabolic diseases. Curr Opin Clin Nutr Metab Care 2005;8:347-354.

32 Weisberg SP, Hunter D, Huber R, Lemieux J, Slaymaker S, Vaddi K, Charo I, Leibel RL, Ferrante AW Jr: CCR2 modulates inflammatory and metabolic effects of high-fat feeding. J Clin Invest 2006; 116:115-124.

33 Keophiphath M, Rouault C, Divoux A, Clement $\mathrm{K}$, Lacasa D: CCL5 promotes macrophage recruitment and survival in human adipose tissue. Arterioscler Thromb Vasc Biol 2010;30:39-45. 
\$4 May AE, Kanse SM, Lund LR, Gisler RH, Imhof BA, Preissner KT: Urokinase receptor (CD87) regulates leukocyte recruitment via beta 2 integrins in vivo. J Exp Med 1998;188:1029-1037.

35 Connolly BM, Choi EY, Gardsvoll H, Bey AL, Currie BM, Chavakis T, Liu S, Molinolo A, Ploug M, Leppla SH, Bugge TH: Selective abrogation of the UPA-PLAUR interaction in vivo reveals a novel role in suppression of fibrin-associated inflammation. Blood 2010;116:1593-1603.
36 Bauer TW, Liu W, Fan F, Camp ER, Yang A, Somcio RJ, Bucana CD, Callahan J, Parry GC, Evans DB, Boyd DD, Mazar AP, Ellis LM: Targeting of urokinase plasminogen activator receptor in human pancreatic carcinoma cells inhibits c-Metand insulin-like growth factor-I receptor-mediated migration and invasion and orthotopic tumor growth in mice. Cancer Res 2005;65:7775-7781.
37 Ohashi K, Parker JL, Ouchi N, Higuchi A, Vita JA, Gokce N, Pedersen AA, Kalthoff C, Tullin S, Sams A, Summer R, Walsh K: Adiponectin promotes macrophage polarization toward an anti-inflammatory phenotype. J Biol Chem 2010;285:6153-6160. 38 Bhandary YP, Velusamy T, Shetty P, Shetty RS, Idell S, Cines DB, Jain D, Bdeir K, Abraham E, Tsuruta Y, Shetty S: Post-transcriptional regulation of urokinase-type plasminogen activator receptor expression in lipopolysaccharide-induced acute lung injury. Am J Respir Crit Care Med 2009; 79: 288-298. 